This work was supported by the H2020 European Research Council under the ERC Starting Grant agreement no. 639668.

\title{
Rachel Beer, The Dreyfus case, and the Observer: The "Sponge Metaphor" ELOISE FORESTIER
}

In September 1894 the French Ministry of War discovered that one of its army officers was spying for the Germans. When a shredded bordereau, a memorandum containing French military secrets, was found at the German embassy, the French Army needed to find a culprit rapidly for this embarrassing security breach. The position and skills of Captain Alfred Dreyfus (18591935) fit with the information found in the memorandum. Dreyfus was also the only Jewish officer in the French Army. In October 1894, Commandant du Paty de Clam was put in charge of the investigation. He summoned Dreyfus and dictated a letter to him based on the memorandum. As the handwriting seemed to match, Dreyfus was arrested for treason, despite his protestations of innocence, and locked up in the prison of the Cherche-Midi. On November 28, 1894, the French daily Le Figaro published an interview with General Mercier, then minister of war, who inappropriately declared before the trial, "La culpabilité de cet officier est absolument certaine" (The guilt of this officer is beyond any doubt). ${ }^{1}$ A meeting of the military court of justice held behind closed doors heard the dubious testimony of a handwriting expert attesting to Dreyfus's authorship of the memorandum. As the judges hesitated, Commandant Henry, the officer of the Intelligence Department who had reported the discovery of the memorandum, presented them with forged evidence collected in a file of documents. This file, referred to as the "secret dossier," was passed on to the judges under Mercier's orders without informing the defence. ${ }^{2}$ 
Dreyfus was court-martialled, imprisoned, and exiled in January 1895. The discovery of new evidence in the case, in 1896, cast serious doubts on Dreyfus's guilt, yet the French Army abided by its code of honour and adhered to the strength of la chose jugée (res judicata). ${ }^{3}$ The army headquarters shielded the true author of the memorandum, Major Ferdinand Walsin Esterhazy, a man of ill repute who had turned spy to pay off his debts. France was divided into two opposing parties: the Dreyfusards, who proclaimed Dreyfus's innocence, and the antiDreyfusards, who maintained his guilt. The two sides were backed by different factions of the French press, which published a variety of articles and pictorial representations. ${ }^{4}$ During the period in which Dreyfus's guilt was under debate, from late 1897 to 1899 , the international press became involved. Media coverage soared from March to September 1899 when the Court of Cassation reviewed the case and eventually quashed the verdict on June 3, 1899. Coverage peaked when Dreyfus was tried for a second time in Rennes (August 7, 1899-September 9, 1899). Dreyfus was found guilty again, this time with “circonstances atténuantes," a French legal expression translated in the English press by "extenuating circumstances." 5 The court used this sentence as a political innuendo, to mask the complexity of the case. In other words, Dreyfus officially became a scapegoat. His guilt protected the army officials who were involved in his arrest, while the "extenuating circumstances" enabled the judge to revoke his prison sentence. British and American critics pronounced the verdict of Rennes unfair, with one calling it "a violation of the laws of civilization."6 The negative reaction of the British press culminated after the second verdict when the French government shirked its responsibility for the scandal by granting Dreyfus a presidential pardon. ${ }^{7}$

One particularly strident Dreyfusard voice came from the Observer, a British weekly edited by Rachel Beer. Beer not only reported on the Dreyfus affair but also took an active part 
in its development by interviewing Esterhazy and, as this essay will show, shifting the key terms of the debate. Borrowing an image from French journalist Jules Cornély's "L'Eponge," an article which appeared in Le Figaro that suggested wiping the slate clean for everyone involved in the case, Beer adapted the sponge metaphor to highlight the injustice suffered by Dreyfus. My study retraces the evolution of this metaphor in the French press and across linguistic boundaries in international newspapers. By situating Beer's use of this metaphor within her editorship of the Observer, I demonstrate her cross-national perspective on the case.

Dreyfus's accusation crystallised anti-Semitic feelings in France. This subplot of the Dreyfus affair was an important side of the multi-facetted scandal, which Cornély also included in his article. I show how the issue of religious ideology was further explored through the sponge metaphor, in caricaturist Henri-Gabriel Ibels's drawing Le Coup de l'Eponge (1899) and other echoes in the international press. I argue that by setting aside the religious implication of the sponge metaphor to focus on the most up-to-date political and legal circumstances of the case, Beer developed a more convincing, justice-orientated strategy. As opposed to evoking an ideological conflict which detached itself from the immediate fate of Dreyfus, she refashioned the sponge into a criticism of Mercier and militarism in France.

\section{Rachel Beer, the Observer, and the Dreyfus Case}

Rachel Beer (1858-1927), née Sassoon, was the first woman editor of two British national Sunday papers: the Observer (1896-1901) and the Sunday Times (1894-1901). ${ }^{8}$ In 1887 she married Frederick Beer, the son of the newspaper baron Julius Beer who had purchased the Observer in 1870. When Rachel and Frederick inherited the paper, it was focused on literature, politics, and foreign affairs and was known for publishing news exclusives. ${ }^{9}$ Such scoops enhanced the newspaper's reputation, but they did not improve its circulation. After he assumed 
the editorship of the Observer in 1893, Frederick Beer reduced its price from four to two pence to make it competitive with penny newspapers. ${ }^{10}$

Rachel Beer began working for the Observer soon after her marriage, but her contributions were not well received by the editorial staff. This prompted Frederick Beer to purchase the Sunday Times, another leading newspaper, of which Rachel became owner and editor. Two years of professional rivalry followed, but the competition never seemed to impede their marital well-being. When Frederick's health declined in 1896, Rachel started editing both the Sunday Times and the Observer. ${ }^{11}$ She respected all his former editorial policies regarding the paper's frequency, price, and format. There were very few images published in the paper, as established years earlier by Julius Beer. Each issue contained eight pages, to which Rachel Beer irregularly added a special edition of up to seven pages in times of war. Her articles and editorial notes were never signed. ${ }^{12}$ The leaders, usually one to three articles, were soberly printed under mastheads with the date and a title. Beer's overview of foreign politics followed in the "Notes" section. She covered news from many countries; indeed, there was only one article on home affairs for every five or six paragraphs on foreign affairs.

Given her prominence in late Victorian print culture, it is surprising that Beer has been the subject of only one biographical study, Eilat Negev and Yehuda Koren's The First Lady of Fleet Street (2011). Although she is not an entirely unknown figure in periodical scholarship, her contribution to periodical history remains rather understudied. ${ }^{13}$ Though Beer's professionalism was hailed by female journalists and activists of her day, scholars now use her as a case study for the "compatibility of home-making and professional roles." 14 By merely adding her name to a list of pioneering women journalists, scholars have overlooked her individual work. Moreover, 
Beer played a significant role in the international development of the Dreyfus case and can be regarded as an actor in the international feminist movement that rallied in his support. ${ }^{15}$

Beer's articles for the Observer are often mentioned within the immense body of work on the Dreyfus case, yet these articles are usually misattributed to Rowland Strong, her correspondent in Paris who met Esterhazy and convinced him to speak to Beer in London. ${ }^{16}$ In L'Affaire Dreyfus de A à Z (1994), Michel Drouin devotes two sentences to Beer that are arguably inspired by Esterhazy's biased memoirs, Les Dessous de l'Affaire Dreyfus (1898). ${ }^{17}$ This significant gap in the scholarship fails to measure the extent of Beer's influence on the history of the case. She was the first to publish Esterhazy's confessions, which appeared in the Observer on September 18 and 25, 1898, under the title "Light upon the Dreyfus Case." Her interviews with Esterhazy boosted the newspaper's circulation considerably. Yet this exclusive was only the first stage in her analysis of the Dreyfus case. Between November 1897 and May 1899, she wrote twenty leaders on the case and as many shorter articles in "Notes." During this period, every issue of the Observer included some coverage of the case. Other articles relating to the affair were mostly reports by Strong (signed "FROM OUR OWN CORRESPONDENT"), Reuters's telegrams informing readers of the latest facts, and notes from French correspondents or experts. ${ }^{18}$

Before Beer entered the debate over the Dreyfus case, the story was already well reported by the Parisian press. The left-oriented periodical L'Aurore (1897-1914), launched by Ernest Vaughan and Georges Clémenceau in October 1897, was the first defender of Dreyfus in the French press. ${ }^{19}$ Clémenceau was the first journalist to remark upon a possible miscarriage of justice in an editorial published on November $1,1897 .{ }^{20}$ The Dreyfusard movement was initiated by the editorial team of Le Figaro, including Emile Zola, who coined the celebrated phrase "la 
vérité est en marche, rien ne l'arrêtera plus" (the truth is forthcoming and nothing can stop it) after the vice president of the Senate Scheurer-Kestner disclosed the conclusions of his inquiry in November $1897 .{ }^{21}$ Zola's position, however, jarred with the declaration made that same month by "Vidi," another editorial writer for Le Figaro: "[Nous voulons] être en cette affaire, pour le public, des informateurs et non pas des commentateurs" (we want to be informers and not commentators in this affair). ${ }^{22}$ Likewise, Jules Cornély, who joined Le Figaro in late December 1897, did not support Zola's public outcry. ${ }^{23}$ The day after Zola was condemned for libel, Cornély wrote a leading article for Le Figaro ending in a call to close the case: "Personne de nous n'a intérêt à ce que dure l'abominable crise que nous venons de traverser. Terminons-la" (No one will benefit from the continuation of the terrible crisis we have gone through. Let's end it). ${ }^{24}$ In other words, Le Figaro debated over the Dreyfus affair yet struggled to maintain a coherent stance. $^{25}$

As the case became prominent in the French press in the following weeks, Beer published her first impressions on November 28, 1897: "The unfortunate man . . . was found guilty by a military tribunal, sitting in secret ... What the nature of the evidence was, what the actual admissions of the accused were, what motive was imputed, and how it was proved, nobody is able to state." 26 Beer immediately understood that the point at issue was not Dreyfus's guilt or innocence but an opposition or support of Republican ideals: as the French Army and government maintained the story of Dreyfus's guilt, to stand as a Dreyfusard meant that one condemned the Republic. ${ }^{27}$ She consequently denounced the lack of transparency and honesty in the case at a relatively early stage. On January 9, 1898, she wrote: "Everything is possible to a tribunal possessed by an over-mastering prejudice which takes no account either of evidence or of common sense." 28 
Beer's judgement anticipates Emile Zola's article in L'Aurore for January 13, 1898, "J'accuse ... !," which denounced the general plot against Dreyfus in an open letter to the President of the French Republic three days after a military trial had established Esterhazy's innocence. The title of the article, chosen by Vaughan and Clémenceau, was a rallying cry. Zola condemned the inertia of the French government and summarized the frustrated efforts of a handful of officers, civilians, politicians, and journalists who had been collecting and publishing proof of Esterhazy's guilt in the face of official denial. The French government reacted immediately by bringing suit against Zola and $L$ 'Aurore. ${ }^{29}$

In "J'accuse. . . !" Zola puts most of the blame on Armand Du Paty de Clam and scorns General Mercier for his "weakness of spirit." ${ }^{\text {"30 }}$ Beer, by contrast, exposes Mercier's responsibility for the actions of Du Paty de Clam. In her leading article for February 13, 1898, she dismisses Du Paty de Clam's "grotesque statement," and names Mercier four times to condemn his reprehensible silence: "Général Mercier refused to answer, and silence in such a case is damning." ${ }^{\prime 11}$ In these first articles on Dreyfus, Beer highlights the dangers of militarism in France with her characteristic irony. For instance, she puts inverted commas around the phrase "the honour of the French army" and sarcastically remarks, "It is plain that France would have another military dictatorship to-morrow, if there were any man popular enough for the job." ${ }^{32}$

When Esterhazy arrived in London on September 1, 1898, Rowland Strong provided him with a bed in his own rooms at 6, St James Street, which belonged to the American journalist Thomas Fielders. There he was interviewed many times by both Strong and Beer and received $£ 500$ for his service. ${ }^{33}$ The resulting article, "Light Upon the Dreyfus Case" has been critically acclaimed as the masterpiece of Beer's career. ${ }^{34}$ The article prompted significant discussion because it appeared the day before the case was referred to the Court of Cassation on September 
26, 1898. The debate on Dreyfus peaked in the French press during that month. ${ }^{35}$ Cornély, for example, published a leading article in Le Figaro entitled "Tranquillité," in which he critiqued the haranguing Dreyfusard speeches of anti-republican leader Paul Déroulède, as exaggeratedly vociferous and ineffectual. ${ }^{36}$

The French press was reluctant to reprint Beer's "Light Upon the Dreyfus Case.” La Fronde, L'Aurore and Le Siècle expressed no wonder at Esterhazy's confessions but acknowledged Beer's article as an important step towards overturning the verdict, while other national newspapers that referred to Beer's articles adopted either a critical or a non-committal stance. ${ }^{37}$ Havas, a French press agency, remarked,

"A journalist for the Observer — who sheltered Esterhazy for ten days — claims to have received from him some details of the utmost interest on the Dreyfus case; and especially with regards to the bordereau. 'The bordereau, he says, was his favourite topic of conversation.' Here follow the terms in which the English journalist makes Esterhazy speak. We reproduce this speech out of sheer curiosity and decline all responsibility as to its content." $" 38$

Most newspapers commented on Esterhazy's financial motivation rather than the content of his confessions. In other words, the reception of "Light Upon the Dreyfus Case" in French newspapers shows that the article did more than reveal Esterhazy's confessions and whereabouts in London to the world; it strongly suggests that Esterhazy's guilt was already known in France. Beer's intervention not only disseminated details of the Dreyfus scandal internationally, but also revealed how the case was being handled, or rather mishandled, in France.

As she continued to publish reports on the Dreyfus case, Beer keenly noted the transformations of a metaphor circulating in the world press during the months preceding the trial in Rennes: passer l'éponge (to wipe the slate clean). Cornély was the first to employ this 
sponge metaphor to discuss the Dreyfus case in his article "L'Eponge" published in Le Figaro on May 23, 1899. Seeking a solution to the social and political crisis in France, he used the expression passer l'éponge to argue that Dreyfus and the military officials who were responsible for the scandal should be forgiven. His article was thus another attempt to stem the tide of agitation surrounding the Dreyfus drama. Cornély’s concluding paragraph asserted, "La meilleure de toutes les politiques, c'est la politique de l'éponge ... Nous nous réclamons de Celui qui a pardonné. Nous pardonnerons" (The best of all politics is the politics of the sponge . . .We claim to belong to He who has forgiven. We will forgive).$^{39}$ The expression passer l'éponge means as much to forget as to forgive. By employing this metaphor, Cornély meant to establish a link between his Catholic ideology and the Dreyfus affair. But the sponge metaphor soon became a political tool: Gaston de Galliffet, the French Minister of War under the Dreyfusard Waldeck-Rousseau government (June 22, 1899-June 7, 1902), recommended Cornély's policy of the sponge in a letter to Le Journal des Débats. ${ }^{40}$ The sponge then travelled through various international publications in France (Le Siècle, Le Temps, L'Aurore), Belgium (L'Indépendance Belge), the Netherlands (Leeuwarder Courant), and Sweden (Dagens Nyheter), where it fostered perplexity and sometimes anger. "Le père de l'éponge pour faussaires" (the father of the sponge for forgers) claimed "G.B.", for L'Aurore on December 25, 1899, in reference to Henry's forged documents, while the Belgian press more politely questioned the intent of French politicians behind the use of the expression: "Mais par ailleurs cette politique du coup d'éponge ne serait-elle point politique de duperie et d'équivoque?" (Would this policy of the sponge not be a policy of deceit and ambiguity?). ${ }^{41}$ 
The development of the sponge's meaning continued with the distortion of Cornély's religious message, that was most clearly illustrated by Henri-Gabriel Ibels in a cartoon that appeared in Le Siècle on September 18, 1899 (figure 1). ${ }^{42}$

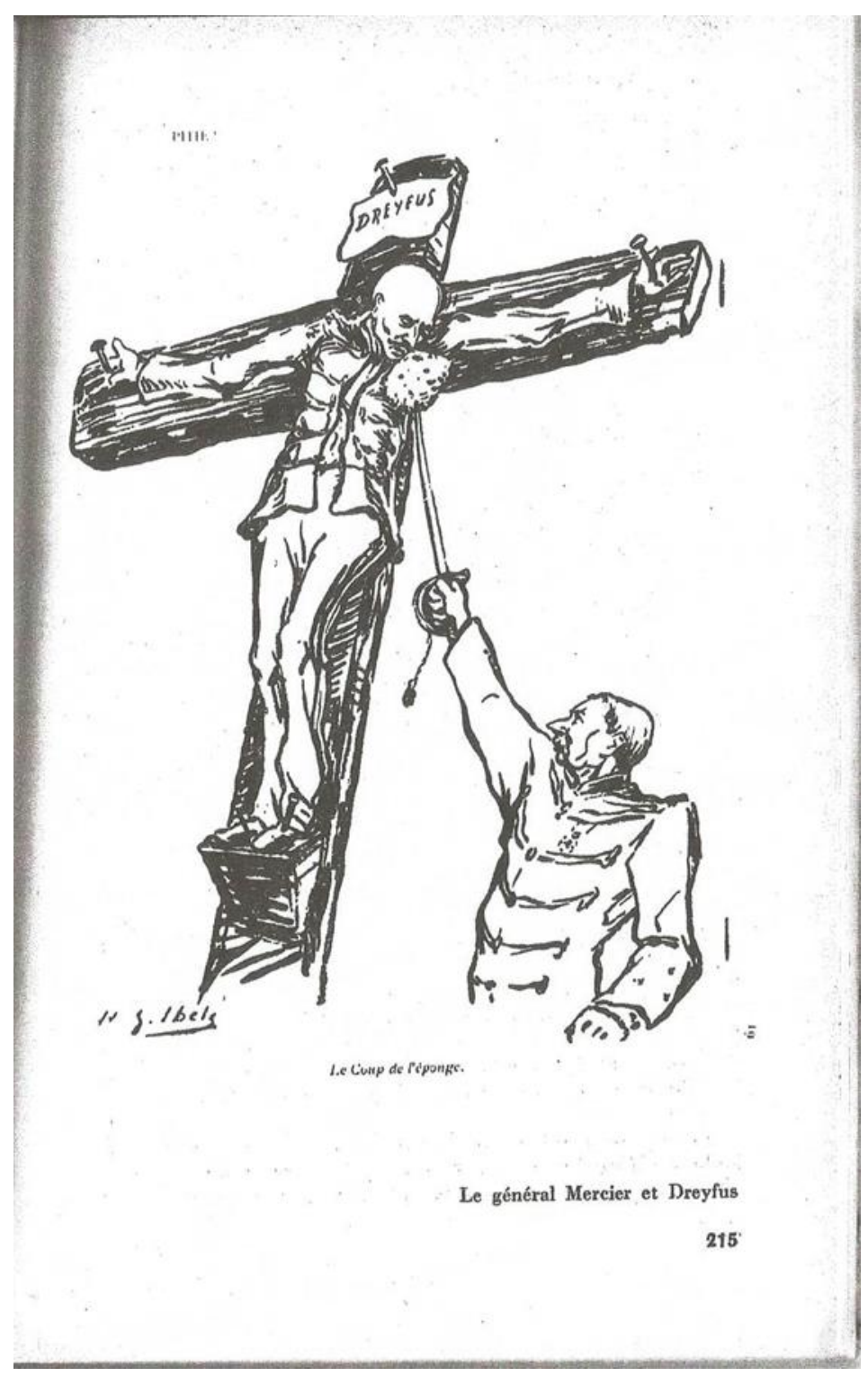

Ibels twisted Cornély's proposal to wipe the slate clean by calling on a more specific biblical reference, the Holy Sponge, which was dipped in sour wine and offered to the dying Jesus. ${ }^{43}$ The sour wine, or vinegar, pointed to the bitter after taste of calls for forgiveness as Dreyfus 
continued to suffer false accusations during the summer of 1899 leading up to the verdict of Rennes. In the drawing, Dreyfus is crucified and nailed to the cross in an analogy to Jesus, who was also a falsely accused Jew. He is fully clad in a tattered army uniform, symbolizing his unbending loyalty to the French Army. ${ }^{44}$ Dreyfus thus sacrifices himself as Jesus offered his life to Christian followers. In the biblical text the sponge is offered on a hyssop branch, a medicinal plant traditionally used for purification and purgation. But here the sponge is placed at the tip of Mercier's sword, signifying that instead of showing mercy to the martyr, General Mercier adds insult to injury and stabs the victim a second time. With his drawing, Ibels picked up with irony the last words of Cornély's article (We claim to belong to He who has forgiven. We will forgive) while he denounced the sponge as a ploy of justice. Yet this religious subplot, which suggests a failed re-enactment of the Christian Crucifixion, supposes that Dreyfus was and would remain a victim.

Le Temps (1861-1942), another Parisian Dreyfusard newspaper second only to Le Figaro in number of daily sales, alluded to the Holy Sponge on September 1, 1899: "On parle beaucoup de 'la politique de l'éponge.' Pour le moment, l'éponge est imprégnée de vinaigre" (A lot is said about the "politics of the sponge". At the moment, the sponge is soaked in vinegar). ${ }^{45} \mathrm{In}$ response, L'Indépendance Belge quipped on September 4, 1899: “Je ne sais pas si on passera l'éponge ... on se contente de ramasser avec cette fameuse éponge allégorique tout le fiel et tout le vinaigre répandus" (I do not know if we will pass the sponge, we keep on soaking up all the bitterness and spilt vinegar with this famous allegorical sponge).$^{46}$ In these echoes and additions to the biblical reference, the sponge is seen as a metaphorically swelling, disgusting object that circulated in the world press, not unlike a fictive representation of the picture of Dorian Gray. The Dutch press suggested to replace the sponge with a more explicit metaphor, 
and another domestic object, the broom, that evokes the need to hide away accumulating filth: "Niet de spons, maar de bezem!" (not the sponge, but the broom!) ${ }^{47}$ Beer did not merely comment on the use of the sponge metaphor nor its various interpretations, she uncovered and exposed it. Beer sought justice by redirecting the sponge metaphor to different aspects of the case, to emphasize the guilt of the army, as personified by General Mercier.

\section{Rachel Beer's "Sponge Metaphor"}

Beer's intervention in this debate culminated in her leader "The Sponge," published in the Observer on September 24, 1899. To understand the full purport of this piece to the unfolding of the case, we must consider how, in the months leading up to the second verdict, Beer employed the sponge metaphor as both a connecting thread and a medium to express her evolving thoughts on the Dreyfus affair.

In "Revision at Last" on June 4, 1899, the day on which Le Figaro announced the Court of Cassation's decision to retry Dreyfus, Beer introduced the sponge metaphor to establish Esterhazy's guilt: “To all his [Esterhazy's] reiterated and vivacious assertions - made to us and to others - of his responsibility for the bordereau, the responsibility of a soldier acting under orders[,] he applied the impartial sponge, and then we and others became, in his eyes, defamers of his character." 48 This passage indicates Beer's stung pride, for she had interviewed and paid Esterhazy for the confessions that he later denied under oath after bringing suit against the Observer. Esterhazy's use of the "sponge," she suggests, is motivated by his deceitful personality. By alluding to Esterhazy's dishonesty, Beer also underlined the deceptive impartiality of the "politics of the sponge." Her peculiar phrase "impartial sponge," which assumed readers' knowledge of the progress of the Dreyfus case, foreshadowed the judge's verdict of Rennes. 
In a "Notes" column published on June 11, 1899, Beer used the metaphor in another context: "there is a proposal before the chamber to apply a sponge to the whole affair." 49 The literal translation of the expression passer l'éponge is to pass the sponge (over something), but Beer mostly used the verb "apply" instead of "pass." By refusing the accepted translation of the French expression, she highlighted not only the difficulty of translating a non-English phrase but also the semantic inadequacy of the expression itself in the context of the Dreyfus case. To "pass" would imply a swift wiping movement, whereas to "apply" suggests dabbing in delicate touches. If Beer's analysis of the situation in France in 1899 were akin to the process of cleaning a tarnished picture, the purpose of the sponge would be to carefully remove layers of falsehood and reveal the truth. As such, Beer did away with the Dreyfusard/antiDreyfusard dichotomy. By employing the sponge metaphor in his account of the Dreyfus case, Cornély inadvertently provided Beer with a tool to clear up the lies and misrepresentations that had plagued the French press. Beer's revision of the metaphor also critiqued the inadequacy of Cornély's approach, which was less focused on discovering the truth than wiping away collective guilt.

In a leader published on June 25, 1899, Beer condemned the "policy of the sponge": "Two months ago he [Galliffet] declared for what is called the policy of the sponge. He proposed to combine justice to Dreyfus and Picquart [head of France's Intelligence Bureau in 1896 who found evidence of Esterhazy's guilt] with an amnesty to the criminals of the Etat Major. That policy might be all very well as a matter of expediency if the criminals would accept their defeat. They accept nothing." ${ }^{50}$ Her use of the passive structure "what is called" distances Beer from the "policy of the sponge" and demonstrates that she will not endorse it. A few lines later, Beer qualifies her reference to "criminals" by noting that the "impudent Mercier is preparing fresh lies for the tribunal at Rennes, . . . no sponge can cure the frenzy of General Mercier." ${ }^{51}$ Beer 
comically depicts Mercier as a fiend whose emotional instability prevents him from accepting the rationality of Galliffet's proposal. Once again, Beer embraces justice rather than compromise, paving the way for her outrage at Dreyfus's condemnation at Rennes, and, later, at the official pardon that ended the Dreyfus case.

On July 23, 1899, Beer denounced the lies that surrounded the Dreyfus case, using the sponge metaphor repeatedly as a rhetorical device: "Now the Minister of War has said that the sponge should be applied to offences on both sides in this miserable affair. He did not know then what offences had still to be disclosed. He cannot think now that any sponge can efface the crime of that telegram ... What is certain is that this is no time for political sponges." ${ }^{52}$ Beer's repeated references to Galliffet's proposal indicate the measure of her indignation. The shift from "the sponge should be applied" to "political sponges" undermines the potential efficiency of the policy. Beer debunks the official proposal by using the expression "political sponge" to playfully mock the original formulation of the "politics of the sponge." In this article she also refers to the humiliations and punishments heaped upon both Alfred Dreyfus and his wife, Lucie. Dreyfus's enemies had hoped that ill-treatment and despair would lead to Dreyfus's death during his incarceration on Devil's Island. He was tortured and put into irons following a rumoured rescue attempt in 1896. Dreyfus was then sent a false telegram asserting that his wife had been unfaithful to him, a deceit which Beer took to heart, triggering another use of the word "sponge."

The verdict of Rennes was reached on September 9, 1899. On September 10, the Observer was saturated with the news of Dreyfus's trial. The contrast between reports on demonstrations from abroad (as reflected in headlines such as "Berlin shocked," "Feeling in Italy," "Execration in New York," "Disgust and Indignation [in London]") and the reported reaction in France (epitomised in the headline "Joy in Paris") demonstrate the disconnect 
between the international and the French response to the verdict. ${ }^{53}$ "The Defeat of Justice," Beer's leader in the Observer on that day, not only crystallized the feeling of shock and revolt that travelled the world with news of the verdict but also expressed her own feelings concerning the case: "This is the view the whole civilized world will take of the new sentence upon an innocent man. Ten years' imprisonment for the crime of being a Jew, for the crime of having survived five years of torture already, for the crime of having proved Mercier to be a villain!" 54 The sarcasm of the second sentence, and the order in which Beer presents the different categories of crime, with her reference Dreyfus's Jewishness placed well before the final exclamation on Mercier, indicates Beer's conviction that the menace of military absolutism in France had supplanted the anti-Semitic subplot of the Dreyfus case. A week later, on September 17, as rumours of the forthcoming presidential grace reached her, Beer collected her thoughts under the title "The 'Pardon"”: "To pardon the innocent is an eccentric proceeding, especially after a trial which was a mockery of justice," and furthermore, "nobody can seriously believe that a pardon will end the "Affaire"." ${ }^{55}$ While "The 'Pardon"” has been recognized as one of the most important articles published in the Observer throughout the nineteenth century, it offers only half of Beer's reflection; she would conclude her reasoning in "The Sponge," published in the next instalment on September 24, 1899. ${ }^{56}$

"The Sponge" article's publication date is significant within the context of the Dreyfus affair: September 24 was as near as it could be to the anniversary of the publication of "Light Upon the Dreyfus Case" and almost exactly four months after Cornély's article. Broadening the metaphor to represent the Dreyfus case and cause, Beer no longer uses the word "sponge" in an experimental way; there is no "applying of" the object, nor does she use adjectives such as "impartial" or "political." These former rhetorical explorations had served to expose the sponge 
as an artifice, while she reminded the world of Dreyfus's humanity, as opposed to the symbolic value of his arrest. Shedding her former playfulness, her tone becomes more solemn and as such, Beer's criticism of the metaphor and what it represents is stronger and harsher. After Cornély's image of a merciful teacher's sponge wiping a blackboard clean, Beer's depiction denounces a misplaced forgiveness that masks incapability and deceit, as France did away with the Dreyfus case without addressing the problems that it raised,

"The policy of the sponge cannot save France from the moral bankruptcy which comes from the stultification of law. If the Republic cannot, or will not, punish forgers and perjurers when they are in uniform, if General de Gallifet thinks it is consistent with his respect for Colonel Picquart to decorate with the League of Honour such a knave as Major Lauth, who vamped up the fraudulent charge about the forgery of the petit bleu, if the inevitable demand of Dreyfus for legal rehabilitation is to be met by another chose jugée, 'this painful conflict' must be perpetuated." 57

In "The Sponge" Beer uses the word "justice" six times, "pardon" five times, and "sponge" four times. These terms form a triangle of forces underpinning Beer's reflection on the Dreyfus case. Whereas Cornély had invoked Christian pardon to justify "la politique de l'éponge," Ibels's drawing overturned this argument and placed the sponge in the centre of the religious subplot of the Dreyfus case. ${ }^{58}$ Beer, however, dismisses this subplot and turns exclusively to the judicial resolution of the affair. In "The Sponge," she deflects the religious overtones of Cornély's article by referring to the presidential pardon: "It would seem that the "pardon" of Captain Dreyfus is the measure of M. Waldeck Rousseau's courage and of General de Gallifet's sympathy with revision." ${ }^{59}$ She writes, "the liberation of the innocent with a stigma on his name is to end the 'Affaire'."60 This cynical statement, in which Beer uses the word 
"stigma," which could also refer to the wounds of Christ, points to the underlying truth of a plain miscarriage of justice in the face of the religious and political arguments that weighed on Dreyfus's name, by disconnecting the public debate from Dreyfus's actual predicament and the wiles of French justice. Beer's last words are a warning: "When Mercier is secure and defiant smaller criminals need not be uneasy. If his crimes are to benefit by the sponge, why not theirs? And to the poor Republic that sponge threatens to be an instrument of ridicule and disaster." ${ }^{61}$ In other words, in this final article, Beer throws the sponge metaphor back at the French while denouncing it as a dangerous innuendo. The shifting metaphor demonstrates how a rhetorical strategy can detach the mind from the seriousness of a crime. The crime of erasing Mercier's guilt has remained a painful stigma on French military history.

\section{Conclusion}

The Dreyfus case fascinated the world and saturated the press at the turn of the century. While the Dreyfusard French perspective focussed on the injustice towards Dreyfus, as Zola articulated in "J'accuse. . . " the foreign press used the case to criticize the French military system. After the second trial in Rennes, former Minister of War General Mercier became a key antiDreyfusard figure in the international press. ${ }^{62}$ This article has shown that during the most decisive years of the Dreyfus scandal, 1898 and 1899, the British editor Rachel Beer played a significant role in bringing the story into the international limelight through her exclusive publications on Esterhazy, her series of articles in the Observer, and her criticism of the sponge metaphor. The highly mediatized Dreyfus case generated images and symbols throughout the world press and the sponge metaphor travelled through the periodical press from Paris to London with a variety of international echoes. Beer's unique adaptation of this metaphor dismisses the religious subplot of the affair to focus on a criticism of militarism in France and the 
responsibility of Mercier. Building upon uses of the trope elsewhere in the press, Beer delved deeper into its meaning than any other journalist did. The history of the sponge metaphor and Beer's role in its formation suggests its important place in the symbolic dictionary of the Dreyfus case and in the international press more broadly.

Ghent University

${ }^{1}$ Leser, “l'espionnage militaire," 1.

${ }^{2}$ The "secret dossier" is the expression used by the press and by historians to refer to a collection of over 500 documents incriminating Dreyfus. In 2012 Pierre Gervais, Pauline Peretz and Pierre Stutin published Le Dossier Secret de l'Affaire Dreyfus in which the content of the "secret dossier" is discussed for the first time in its entirety.

${ }^{3}$ res judicata refers to a legally judged matter. It is used as an expression to prevent injustice to the parties of a case supposedly finished.

${ }^{4}$ For an example of the many contemporary collections of press caricatures, see Grand-Carteret, L'affaire Dreyfus et l'image. For a comprehensive catalogue of the pictorial press during the affair, see Kleeblatt, The Dreyfus Affair.

${ }^{5}$ See Boussel, L'Affaire Dreyfus et la presse; Cahm and Citti, Les Représentations de l'affaire Dreyfus; Brennan, The Reflection of the Dreyfus Affair; Wilson in Denis, Lagrée and Veillard, L'affaire Dreyfus.

${ }^{6}$ Harding, Dreyfus, 335.

${ }^{7}$ The British outrage was also an opportunity to promote sensational journalism and vent some political tensions (Cornick, “The Dreyfus Affair," 508). 
${ }^{8}$ The first issue of the Observer, the oldest of Britain's national newspapers, came out on December 4, 1791. The weekly periodical pledged to publish "safe and grounded information" through the observation of society and politics and aimed to preserve "intellectual purity" (Miliband, The Observer, ix). Although the Observer was already a success at the end of the eighteenth century, with a circulation of about 6,000 copies, it shifted its focus to gossip and crime at the beginning of the nineteenth century to attract more readers. Circulation rose to an average of 15,000 copies with record sales of over 60,000 for special events such as the coronation of George IV on July 19, 1821. The figure dropped to 3,000 in 1860, the result of renewed sobriety and unpopular support of the North during the American Civil War.

${ }^{9}$ It was the first to announce the capture of Napoleon III and the defeat of Sedan in a special noon edition on September 4, 1870.

${ }^{10}$ The Sunday Times cost one penny.

${ }^{11}$ In an interview for Woman, Rachel Beer described to Arnold Bennett her vision of her responsibilities for the Observer: "I recognize that though I am his wife, I do not own the Observer, and I am far more scrupulous concerning my work for it, than for my Sunday Times, which is quite my own property" (quoted in Negev and Koren, The First Lady of Fleet Street, 199).

${ }^{12}$ Beer's name is mentioned only once in the Observer in the by-line for "Light Upon the Dreyfus Case": "a conversation with the directress of the Observer, Mrs Rachel Beer." Beer's work with Esterhazy enables us to ascertain the authorship of her leading articles and "Notes," which are written in the same style with similar points of reference. See for example Esterhazy's Les Dessous de l'Affaire Dreyfus (especially chapters six and seven). 
${ }^{13}$ Beer is briefly discussed in Onslow's Women of the Press in Nineteenth-Century Britain and only mentioned in a few lines of Demoor's "Editors and the Nineteenth-Century Press," 101. ${ }^{14}$ Onslow, Women of the Press in Nineteenth-Century Britain, 20. Onslow emphasizes Beer's role as a society hostess, but in the nineteenth century the Woman's Signal (1894-99) closely followed and praised the advancement of Beer's career: "The appointment of Mrs. Beer to the editorship of the Sunday Times adds one more to the list of women's successes in journalismthis one perhaps the most brilliant, the Sunday Times being the only general newspaper that has a woman at its head" (“Concerning Women," 215).

${ }^{15}$ As Blum and Carduner-Loosefelt argue, 'L'Affaire offre aux femmes une possibilité tout à fait inédite de se mobiliser en tant qu'intellectuelles, notamment dans les universités populaires, dans les revues, dans les réseaux et bien sûr dans la presse" (The Affair gave women an excellent opportunity to mobilize as intellectuals, in public universities, journals, networks and of course in the press) "Du Genre en Histoire des Intellectuels," 137. See note 37 for more on Beer's position in the international feminist movement surrounding the affair.

${ }^{16}$ See for example Boussel, L'Affaire Dreyfus et la presse, Wilson, L'Affaire Dreyfus et l'opinion publique, Oriol, L'Affaire Dreyfus, Joly, Histoire Politique de l'Affaire Dreyfus.

${ }^{17}$ Drouin arguably describes Beer's relation to the case from his interpretation of Esterhazy's memoirs: "Ses exigences excessives vont en effet le brouiller avec l'Observer, dont la propriétaire, Mrs Beer, n'hésitera pas, avec une totale absence de scrupules, à publier, sans les payer à leur auteur, les confidences faites sans méfiance à Strong. Ainsi grugé, l'escroc en sera réduit à démentir aussitôt et à intenter une couteuse action judiciaire contre Mrs Beer. Pour une fois le bon droit est de son côté [...]" (His excessive demands cause him to quarrel with the Observer, whose unscrupulous proprietor, Mrs Beer, will not hesitate to publish the revelations 
he had unsuspectingly confided in Strong. Thus cheated, the scoundrel was forced into immediate denial and bring a costly legal action against Mrs Beer. For once law is in his favour) (L'Affaire Dreyfus, 177 - 178). See Esterhazy's memoirs: “Mme Beer, Strong et Cie ont essayé d'abuser de la situation précaire dans laquelle je me trouvais, loin de mon pays, sans appui, sans un conseil, pour me prêter des aveux que je ne leur avais jamais faits et pour publier, malgré moi, des documents que j'avais confiés à Strong, comme à mon ami, mais nullement à Mme Beer pour ses journaux." (Mrs Beer, Strong, \& co tried to take advantage of the precarious situation which I was in, far from my country, with no support or counsel, to make up confessions I had never made and publish, in spite of me, some documents that I had placed in Strong's care, as a friend, but never for Mrs Beer and her newspapers) (Les Dessous de l'Affaire Dreyfus, 96). ${ }^{18}$ French Correspondent, "The Key to the Mystery," 5; Dixi, "The Case of Colonel Picquart 'The Plot Revealed," 5; Dixi, "The Origins of the Bordereau," 5.

${ }^{19}$ It was followed by Le Siècle that became Dreyfusard in January 1898. L'Aurore was a fourpage daily newspaper with a circulation of 25,000 in 1898 . It reported record sales of 300,000 copies for Zola's “J'accuse. . .!" on January 13, 1898, and around 150,000 for several weeks after the publication. In 1899 circulation dropped to 15,000 as the readership disapproved of editor Urbain Gohier's anti-military views (Ponty, 'La presse quotidienne et l'affaire Dreyfus en 1898-1899," 195).

${ }^{20}$ The new head of the Intelligence Bureau, Colonel Picquart, found evidence of Esterhazy's guilt with the discovery of the petit bleu, another note located in the German Embassy in March 1896. After enquiry he communicated it to Auguste Scheurer-Kestner, the vice President of the Senate, but the government turned a deaf ear to these appeals (Clémenceau, "L'affaire Dreyfus," 1). This was the first of 665 articles Clémenceau wrote about the case. 
${ }^{21}$ Zola, "M. Scheurer-Kestner," 1. The Parisian liberal and conservative Figaro is the oldest national daily newspaper still in print in France. It was one of the most respected periodicals in the world at the end of the nineteenth century, even though in France in 1898 its circulation was only 40,000 .

${ }^{22}$ Vidi, "Le dossier de M. Scheurer-Kestner," 1.

${ }^{23}$ See Lafage's article for Le Gaulois, "A travers la presse: l'incident Cornély." ${ }^{24}$ Cornély, "La condamnation," 1.

${ }^{25}$ These misunderstandings within the editorial team and conflicting views in articles affected the circulation of Le Figaro, which dropped to 30,000 in 1899 (and 20,000 in 1901 compared to 75,000 in 1896). During the Dreyfus affair, however, Le Figaro remained the most widely read journal of opinion in France and abroad.

${ }^{26}$ Beer, "The Secret Trial," 4.

${ }^{27}$ See the analysis of Henri Opper de Blowitz, "The French Press and the Dreyfus Case."

${ }^{28}$ Beer, "The Dreyfus Case," 4.

${ }^{29}$ The trial took place February 7-23, 1898. Zola was condemned to the maximum penalty: 3,000 francs and a year in prison.

${ }^{30}$ Zola, "J'accuse. . . !," 1-2.

${ }^{31}$ Beer, "the Zola Trial," 4.

${ }^{32}$ Beer, "Notes," January 16, 1898, 4, and "The Military Crisis in France," 4.

${ }^{33}$ Maguire, Ceremonies of Bravery, 147, and Thomas, Esterhazy, 347.

${ }^{34}$ Trelford, The Observer at 200, 2. 
${ }^{35}$ Ponty argues, "Il n'est pas d'autre mois plus fécond en bouleversements d'opinion que Septembre 1898" (No month witnessed so many shifts of opinion than September 1898) ("La presse quotidienne et l'affaire Dreyfus en 1898-1899," 216).

${ }^{36} \mathrm{He}$ wrote, "On écoute avec un dilettantisme parfait, des discours qui ressemblent à des coulées de lave et des articles qui ressemblent à des aspersions de vitriol" (We listen with indifferent dilettantism to speeches that flow like spurts of lava and read articles that run like splashes of vitriol) (Cornély, “Tranquillité," 1). Cornély pursued this line of thought in September 1898, even though he was finally convinced of Dreyfus's innocence after the confessions and suicide of Colonel Henry, the forger of the documents in the secret dossier: "Organisons un désarmement moral. Car personne, absolument personne, excepté peut être les vendeurs de journaux, n'a intérêt à ce que continue cette lutte impie, fratricide et sans issue (We must organise a moral disarming. Because no one, absolutely no one, except perhaps newsagents, will benefit from this ungodly, fratricide and hopeless fight) (Cornély, "Le drame," 1). When Le Figaro published the record of the inquiry of the Court of Cassation in daily instalments from March 31 to June 4, 1899, Cornély was convinced that Dreyfus's innocence would tip justice in his favour. He also acknowledged the injury left by the miscarriage of justice: "Insensés qui ignorent que cacher une plaie ce n'est pas la guérir!" (Fools who believe that hiding a wound will heal it!) (Cornély, "La Dernière Semaine," 1). For a portrait of Cornély and his opinions see Oriol, L'Affaire Dreyfus, 799-800.

${ }^{37}$ The feminist French journal La Fronde (1897-1905), edited by Marguerite Durand, was a fervent supporter of Dreyfus and a friend of Beer: "Mrs Beer is a worthy and intelligent lady, a strong feminist and a great friend of the Fronde" ([Durand], "Les Aveux d'Esterhazy," 1). In 
L'Aurore and Le Siècle, see Dubois, "Les Aveux d'Esterhazy," 1-2, and Reinach, "Les Aveux du Uhlan," 1.

${ }^{38}$ The article ran in Le Figaro and Le Siècle: "Un rédacteur de l'Observer-qui a donné l'hospitalité à Esterhazy pendant dix jours—dit avoir reçu de lui des détails du plus grand intérêt sur l'affaire Dreyfus ; mais surtout en ce qui concerne le bordereau. 'Le bordereau, dit-il, était le thème favori dans ses conversations.' Voici en quels termes le journaliste anglais, dont nous reproduisons le récit à titre de curiosité et en lui laissant toute la responsabilité, fait parler Esterhazy” (Daremay, "L'article de l'Observer”, 2; “Esterhazy et le bordereau,” 1). ${ }^{39}$ Cornély, “L’Eponge,” 1.

${ }^{40}$ In early June 1899, he had confided this in a letter to his friend Geneviève Straus, a French salonnière: "Une idée fixe: l'éponge de M. Cornély que je me suis permis de recommander dans une lettre aux Débats." (An idée fixe : M. Cornély's sponge, that I recommended in a letter to the Débats) (Leymarie, La Postérité de l'Affaire Dreyfus, 38). I have not been able to find a published letter in Le Journal des Débats, however, on June 10, 1899, the content of Galliffet's proposal is referred to, without the reference to the sponge, in a short paragraph ("Une proposition d'amnistie" under the larger heading "L'AFFAIRE DREYFUS," 2). Since the beginning of the case the ministers of war who succeeded Mercier (Jean-Baptiste Billot, Jacques Godefroy Cavaignac, Emile Zurlinden, Jules Chanoine, Charles de Freycinet, and Camille Krantz) had all been avowed antiDreyfusards in a united effort to protect the word and virtue of the army. Galliffet, nominated by Waldeck Rousseau to the same post on June 22, 1899, was known to be more favourable to Dreyfus.

${ }^{41}$ B.G., "L'Eponge," 1; L'Independance Belge, "France - Courrier de Paris," 1. The Swedish press only reported on the use of the expression with no comment as to its interpretation. 
${ }^{42}$ Ibels's album Les Légendes du du "Siècle" (1899) holds the drawing that appeared in Le Siècle. The drawing was so popular that Ibels reproduced it several times. One copy is dedicated to Joseph Reinach, a fervent Dreyfusard whose son Adolphe was the son-in-law of Mathieu Dreyfus. It can be found at the Bibliothèque Nationale de France (BNF). Norman Kleeblatt published a copy of the drawing that Ibels had sent to his friend Arthur Byl residing in America, which then became part of the collection of Mr. and Mrs. Herbert D. Schimmel, of New York (Kleeblatt, The Affaire Dreyfus, 260).

${ }^{43}$ According to John 19: 29-30, "A jar of wine vinegar was there, so they soaked a sponge in it, put the sponge on a stalk of the hyssop plant, and lifted it to Jesus' lips. When he had received the drink, Jesus said, 'It is finished.' With that, he bowed his head and gave up his spirit" (New International Version).

${ }^{44}$ This drawing endows him with dignity in contrast to the caricature of a stripped Esterhazy on a cross that appeared in Le Sifflet on March 10, 1899 Chevalier, "Ecce Homo," 2.

${ }^{45}$ Linguet, "Le Procès de Rennes," 1.

${ }^{46}$ Jean-Bernard, "Le Procès de Rennes," 2.

47 “Buitenlandsch Overzicht," 1.

${ }^{48}$ Beer, "Revision at Last," 4.

${ }^{49}$ Beer, "Notes," June 11, 1899, 4. Beer probably refers to Galliffet's mediation with Le Journal des Débats (see note 43).

${ }^{50}$ Beer, "The Crisis in France," 4.

${ }^{51}$ Ibid.

${ }^{52}$ Beer, "Justice at Rennes," 4. 
${ }^{53}$ Our Correspondent, "Berlin Shocked," 6; "Feeling in Italy," 6; "Execration in New York," 6; "Receipt of the News in London. Disgust and Indignation," 6; [Strong], "Joy in Paris," 6.

${ }^{54}$ Beer, "The Defeat of Justice," 4 . This article interestingly contains one of the few references to Dreyfus's Jewishness throughout Beer's coverage of the case.

${ }^{55}$ Beer, "The 'Pardon,"” 4.

${ }^{56}$ Miliband included the essay in her anthology, The Observer of the 19th Century; as she explained, "The extracts are those which catch the eye in the middle of the twentieth century $[\ldots]$ they are put together not only to illustrate events but to recapture moods" Miliband, vii.

${ }^{57}$ Beer, "The Sponge," 4.

58 “La meilleure de toutes les politiques, c'est la politique de l'éponge . . . Nous nous réclamons de Celui qui a pardonné. Nous pardonnerons" (The best of all politics is the politics of the sponge ... We claim to belong to He who has forgiven. We will forgive). Cornély, "l'Eponge," 1.

${ }^{59}$ Beer, "The Sponge," 4.

${ }^{60}$ Ibid.

${ }^{61}$ Ibid.

${ }^{62}$ Stead's September article in the Review of Reviews points to the responsibility of the army. Immediately after the Dreyfus scandal the world press turned to the Transvaal crisis. Stead published a pro-Boer pamphlet in which he compares Joseph Chamberlain, Minister for the Colonies, to General Mercier (Cornick, "The Dreyfus Affair," 504).

\section{BIBLIOGRAPHY}

[Beer, Rachel.] "Notes.” Observer, November 14, 1897, 4. . "The Crisis in France." Observer, June 25, 1899, 4. 
. "The Defeat of Justice." Observer, September 10, 1899, 4.

__. "The Dreyfus Case.” Observer, January 9, 1898, 4.

_ . "The French Army and the Church." Observer, July 24, 1898, 4.

__. "Justice at Rennes." Observer, July 23, 1899, 4.

__. "Light Upon the Dreyfus Case." Observer, September 18, 1898: 5.

__. "Light Upon the Dreyfus Case." Observer, September 25, 1898, 5.

_ . "The Military Crisis in France." Observer, February 20, 1898, 4.

—. "Notes." Observer, January 16, 1898, 4.

__. "Notes." Observer, June 11, 1899, 4.

—_. "The 'Pardon." Observer, September 17, 1899, 4.

__. "Revision at Last." Observer, June 4, 1899, 4.

—_. "Secret Trial." Observer, November 28, 1897, 4.

—_. "The Sponge." Observer, September 24, 1899, 4.

—. "The Trial." Observer, September 10, 1899, 5.

_. "The Zola Trial." Observer, February 13, 1898, 4.

B. G. "L’Eponge.” L'Aurore, December 25, 1899, 1.

Blowitz, Henri Georges Stéphane Adolphe Opper de. "The French Press and the Dreyfus Case." North American Review 169, no. 515 (October 1899): 577-92.

Blum, Françoise, and Muriel Carduner-Loosefelt. "Du Genre en Histoire des Intellectuels. Table Ronde." Mil Neuf Cent. Revue d'Histoire Intellectuelle (Cahiers Georges Sorel) 16 (1998): 13343.

Boussel, Patrice. L'Affaire Dreyfus et la presse. Paris: Armand Colin, 1960.

Brennan, James Franklin. The Reflection of the Dreyfus Affair in the European Press, 1897- 
1899. New York: Peter Lang, 1998.

“Buitenlandsch Overzicht.” Leeuwarder Courant, June 7, 1899, 1.

Cahm, Eric, and Pierre Citti. Les Représentations de l'affaire Dreyfus dans la presse en France et à l'étranger. Actes du colloque de Saint-Cyr-sur-Loire. Tours: Université François-Rabelais, 1994.

Chevalier, Louis. "Ecce Homo.” Le Sifflet, March, 10, 1899, 2.

Clémenceau, Georges. “L’affaire Dreyfus.” L'Aurore, November 1, 1897, 1.

Collin, Alfred M. The Observer and J. L. Garvin 1908-1914. London: Oxford University Press, 1960.

“Concerning Women.” Woman's Signal 40, (October 4, 1894): 215.

Cornély, Jules. “La condamnation.” Le Figaro, February 24, 1898, 1.

—_. "La Dernière Semaine.” Le Figaro, May 22, 1899, 1.

—. "Le drame." Le Figaro, September 1, 1898, 1.

—_. "L’Eponge.” Le Figaro, May 23, 1899, 1.

—. Notes Sur l'Affaire Dreyfus. Paris: Editions du Figaro, 1899.

——. "La Politique de l'Eponge.” Le Figaro, June 7, 1899, 1.

—. "La Révision.” Le Figaro, May 28, 1899, 1.

—_. "Tranquillité.” Le Figaro, September 26, 1898, 1.

Cornick, Martyn. "The Dreyfus Affair-Another Year, Another Centenary. British Opinion and the Rennes Verdict, September 1899." Modern \& Contemporary France 7, no. 4 (1999): 499508.

Daremay, G. “L'article de l'Observer.” Le Figaro, September 26, 1898, 2. 
Demoor, Marysa. "Editors and the Nineteenth-Century Press." The Routledge Handbook to Nineteenth-century British Periodicals and Newspapers, edited by Andrew King, Alexis Easley and John Morton. London: Routledge, 2016, 89-101.

- Marketing the Author: Authorial Personae, Narrative Selves and Self-Fashioning, 1880-1930. Basingstoke: Palgrave Macmillan, 2004.

Dixi. “The Case of Colonel Picquart—'The Plot Revealed.” Observer, December 4, 1898, 5.

— . "The Origins of the Bordereau." Observer, December 11, 1898, 5.

Drouin, Michel. L'Affaire Dreyfus de A à Z. Paris: Flammarion, 1994.

—. L'Affaire Dreyfus: Dictionnaire. Paris: Flammarion, 2006.

Dubois, P. H. “Les Aveux d'Esterhazy.” L'Aurore, September 26, 1898, 1-2.

Duclert, Vincent. L'Affaire Dreyfus. Paris: Larousse, 2009.

—. Dreyfus est innocent!: Histoire d'une affaire d'état. Paris: Larousse, 2006.

Duclert, Vincent, with Perrine Simon-Nahum. L'Affaire Dreyfus: les événements fondateurs. Paris: Armand Colin, 2009.

[Durand, Marguerite]. "Les Aveux d'Esterhazy.” La Fronde, September 26, 1898, 1.

“Esterhazy et le bordereau." Le Siècle, September 26, 1898, 1.

Esterhazy, Ferdinand Walsin. Les Dessous de l'Affaire Dreyfus. Paris: Fayard Frères, 1898.

“Execration in New York." Observer, September 10, 1899, 6.

"Feeling in Italy." Observer, September 10, 1899, 6.

Forth, Christopher E. The Dreyfus Affair and the Crisis of French Manhood. London: Johns Hopkins University Press, 2004.

“France — Courrier de Paris.” L'Indépendance Belge, October 20, 1899, 1.

French Correspondent. "The Key to the Mystery." Observer, November 13, 1898, 5. 
Garvin, James Louis. The Observer 1791-1921: A Short Record of One Hundred and Thirty

Years. London: Observer House, 1922.

Gervais, Pierre, Pauline Peretz and Pierre Stutin. Le Dossier Secret de l'Affaire Dreyfus. Paris: Alma éditeur, 2012.

Grand-Carteret, John. L'affaire Dreyfus et l'image: 266 caricatures françaises et étrangères. Flammarion: Paris, 1898.

Guiral, Pierre, Jacques Godechot, and Claude Bellanger. Histoire générale de la presse française, tome 3: De 1871 à 1940. Paris : PUF, 1972.

Harding, William. Dreyfus: The Prisoner of Devil's Island. New York: Associated Publishing Company, 1899.

Harris, Ruth. The Man on Devil's Island: Alfred Dreyfus and the Affair that Divided France. London: Allen Lane, 2010. L'homme de l'île du Diable. Une histoire des passions dans l'affaire Dreyfus. Paris: Presses de la Cité, 2015.

Hatton, Joseph. Journalistic London: Being a Series of Sketches of Famous Pens and Papers of the Day. London: S. Low, Marston, Searle, \& Rivington, 1882.

Ibels, Henri-Gabriel. Les Légendes du "Siècle" Album de Dessins. Paris: Le Siècle, 1899.

—. "Pitié!” Le Siècle, September 18, 1899, 2.

Jean-Bernard. “Le Procès de Rennes.” L'Indépendance Belge, September 4, 1899, 2.

Joly, Bertrand. Histoire Politique de l'Affaire Dreyfus. Paris: Fayard, 2014.

Kleeblatt, Norman. The Dreyfus Affair: Art, Truth and Justice, Berkeley: University of California Press, 1987.

Lafage, Paul. “A travers la presse: l'incident Cornély.” Le Gaulois, December 23, 1897, 2.

“L’Affaire Dreyfus," “Une proposition d'amnistie” Le Journal des Débats, (June 10, 1899): 2. 
Lazare, Bernard. Une Erreur Judiciaire: l'Affaire Dreyfus. Paris: Stock, 1897.

Leser, Charles. “L’espionnage militaire.” Le Figaro, November 28, 1894, 1.

Leymarie, Michel. La Postérité de l'Affaire Dreyfus. Orléans: Presses Universitaires du Septentrion, 1998.

Linguet, G. "Le Procès de Rennes." Le Temps, September 1, 1899, 1.

Le liseur. "Revue des Journaux." Le Figaro, October 8, 1899, 3.

Maguire, Robert J. Ceremonies of Bravery: Oscar Wilde, Carlos Blacker, and the Dreyfus Affair.

Oxford: Oxford University Press, 2013.

Miliband, Marion. The Observer of the 19th Century. London: Longmans, 1966.

Negev, Eilat, and Yehuda Koren. The First Lady of Fleet Street: The Life of Rachel Beer:

Crusading Heiress and Newspaper Pioneer. New York: Bantam, 2011.

Onslow, Barbara. Women of the Press in Nineteenth-Century Britain. Basingstoke: Palgrave

Macmillan, 2000.

Oriol, Philippe. L'Affaire Dreyfus. Paris: Belles Lettres, 2014.

Our own Correspondent. "Berlin Shocked.” Observer, September 10, 1899, 6.

Perthuis, Bruno de. "Images de la justice au temps de l'Affaire Dreyfus." Sociétés et Représentations 18 (2004): 135-45. Cairn. https://www.cairn.info/revue-societes-etrepresentations-2004-2-page-135.htm.

Ponty, Janine. "La presse quotidienne et l'affaire Dreyfus en 1898-1899." Revue d'Histoire Moderne et Contemporaine 21-22 (1974): 193-220.

Rambaud, A. “Politique d'Apaisement.” Le Matin, June 8, 1899, 1.

"Receipt of the News in London. Disgust and Indignation." Observer, September 10, 1899, 6. 
Reinach, Joseph. "Les Aveux du Uhlan.” Le Siècle, September 26, 1898, 1.

—. Histoire de l'Affaire Dreyfus. Vol. 2, "Esterhazy.” Paris: Eugène Fasquelle, 1903.

Stead, William Thomas. “Character Sketch.” Review of Reviews, September 1899, 241-45.

[Strong, Rowland]. "Further Violent Scenes in France." Observer, January 30, 1898, 5.

—. "Joy in Paris." Observer, September 10, 1899, 6.

—_. "Wild Scene in the Chamber_Free Fight among Deputies." Observer, January 23, $1898,5$.

Thomas, Marcel. Esterhazy ou l'envers de l'Affaire Dreyfus. Paris: Vernal Philippe Lebaud, 1989.

Tillier, Bertrand. Les Artistes et l'Affaire Dreyfus 1898-1908. Seyssel: Champ Vallon, 2009.

Trelford, Donald, ed. The Observer at 200. London: Quartet Books, 1992.

"Utrikespolitik." Dagens Nyheter, October 16, 1899, 3.

Vaughan, Ernest. Souvenirs sans regrets. Paris: F. Juven, 1902.

Vidi. “Le dossier de M. Scheurer-Kestner.” Le Figaro, November 14, 1897, 1.

Wilson, Nelly. "Paroles et silences: réflexions sur le rôle joué par la presse britannique dans

l'affaire Dreyfus." In L'Affaire Dreyfus et l'opinion publique en France et à l'étranger, edited by

Michel Denis, Michel Lagrée and Jean-Yves Veillard, 291-303. Rennes: PUR, 1995.

Zola, Emile. “J'accuse ... !" L'Aurore, January 13, 1898, 1-2.

. “M. Scheurer-Kestner.” Le Figaro, November 25, 1897, 1. 